\title{
Climate variability impacts on wheat productivity in central Punjab
}

\author{
P. K. KINGRA \\ School of Climate Change and Agricultural Meteorology \\ Punjab Agricultural University, Ludhiana 141 004, India \\ e-mail:pkkingra@pau.edu
}

\begin{abstract}
Long-term (1970-71 to 2014-15) climatic variability analysis during wheat growing period of Ludhiana indicated significant increasing trend in minimum temperature $\left(0.06^{\circ} \mathrm{C}\right.$ year $\left.{ }^{-1}\right)$ and decreasing trend in sunshine hours $\left(0.03 \mathrm{hrs} \mathrm{day}^{-1}\right)$ and wind speed $\left(0.03 \mathrm{~km} \mathrm{hr}^{-1}\right)$. Lower minimum temperature, relative humidity, rainfall and number of rainy days during the reproductive growth period of wheat covering the months of February and March have been found favourable for higher grain yield. Multiple regression model developed between weather parameters during critical periods and grain yield of wheat explained $81 \%$ variation in wheat productivity. Verification of this model for three years depicted under-estimation of wheat yield between $4-8 \%$.
\end{abstract}

Key words: Climate variability, wheat productivity, agrometeorological models, yield prediction

Wheat is the major cereal crop of indo-gangetic plains in India including Punjab state. Punjab covering only $1.54 \%$ of the geographical area of India, contributes nearly $43 \%$ of wheat and $28 \%$ of rice to the central pool of foodgrains (Annonymous 2015). Wheat, being a winter crop, is adapted to cooler conditions and thus, is more adversely affected by high temperature conditions as compared to rice. Rao et al (2015) reported that Indian wheat yields are becoming more sensitive to minimum temperature especially during post-anthesis period. Exposure to continual minimum temperature exceeding $12^{\circ} \mathrm{C}$ for 6 days and terminal heat stress with maximum temperature exceeding $34^{\circ} \mathrm{C}$ for 7 days during post-anthesis period, are the other thermal constraints in achieving high productivity. Hundal and Kaur (2007) reported that with increase in temperature above normal, phenological development of wheat was advanced. With increase in temperature by $1^{\circ} \mathrm{C}$, wheat yield decreased by $10 \%$ under Punjab conditions.

The present study was thus initiated to analyse the climate variability during wheat growing period and its impact on crop productivity by developing agrometeorological yield forecasting models so as to quantify the influence of climatic variations on crop productivity and pre-harvest yield estimation for agricultural sustainability and food security in the region.

\section{MATERIALS AND METHODS}

Long-term meteorological records for the period 197071 to 2014-15 during wheat growing season for Ludhiana were collected from the Agrometeorological Observatory, School of Climate Change \& Agricultural Meteorology, Punjab Agricultural University, Ludhiana. Trend analysis and variability in long-term climatic records during the wheat growing period were studied to assess the long-term climatic variability during crop seasons and its impact on wheat yield. The relationships between crop yield and mean weekly weather parameters during the growing period of wheat were studied by developing correlation analysis.

The critical periods during which these weather parameters significantly influenced the crop yield, were identified and used to develop multiple linear regression models for predicting the influence of these parameters on crop yields.

\section{RESULTS AND DISCUSSION}

\section{Climate variability during wheat growing period}

Long-term trend analysis of meteorological conditions during wheat growing period in central Punjab indicates large year-to-year and long-term variability. Although no significant trend has been observed in the maximum temperature, but in minimum temperature a significant increasing trend $\left(0.06^{\circ} \mathrm{C}_{\text {year }}{ }^{-1}\right)$ has been observed (Table 1). A significant annual decrease in sunshine hours $\left(0.03 \mathrm{hrs} \mathrm{day}^{-1}\right)$ and wind speed $\left(0.03 \mathrm{~km} \mathrm{hr}^{-1}\right)$ has been observed. A significant increasing trend has also been observed in the morning relative humidity $\left(0.1 \%\right.$ year $\left.^{-1}\right)$, but no significant trend in evening relative humidity, rainfall and number of rainy days. 
Table 1: Long-term climatic variability $(1970-2014)$ during wheat growing period in central Punjab

\begin{tabular}{lllll}
\hline Parameter & Regression equation & $\mathrm{R}^{2}$ & Trend & Annual rate of change \\
\hline Maximum temperature $\left({ }^{\circ} \mathrm{C}\right)$ & $\mathrm{Y}=0.000 \mathrm{X}+22.56$ & 0.000 & - & No change \\
Minimum temperature $\left({ }^{\circ} \mathrm{C}\right)$ & $\mathrm{Y}=0.055 \mathrm{X}+7.223$ & 0.631 & $\uparrow$ & $0.06^{\circ} \mathrm{C}$ \\
Sunshine hours $\left(\mathrm{hrs} \mathrm{day}^{-1}\right)$ & $\mathrm{Y}=-0.034 \mathrm{X}+8.173$ & 0.289 & $\downarrow$ & $-0.03 \mathrm{hrs} \mathrm{day}^{-1}$ \\
Wind speed $\left(\mathrm{km} \mathrm{day}^{-1}\right)$ & $\mathrm{Y}=-0.026 \mathrm{X}+4.382$ & 0.518 & $\downarrow$ & $-0.03 \mathrm{~km} \mathrm{day}^{-1}$ \\
Morning relative humidity $(\%)$ & $\mathrm{Y}=0.108 \mathrm{X}+89.78$ & 0.557 & $\uparrow$ & $0.11 \%$ \\
Evening relative humidity $(\%)$ & $\mathrm{Y}=0.109 \mathrm{X}+41.32$ & 0.046 & $\uparrow$ & $0.05 \%$ \\
Rainfall $(\mathrm{mm})$ & $\mathrm{Y}=-0.016 \mathrm{X}+107.6$ & 0.000 & - & No change \\
Number of rainy days (days) & $\mathrm{Y}=0.013 \mathrm{X}+8.7$ & 0.001 & - & No change \\
\hline
\end{tabular}

Table 2: Correlation between weekly weather parameters and wheat productivity

\begin{tabular}{|c|c|c|c|}
\hline Sr. no. & Weather parameter & Critical period & Correlation \\
\hline 1 & Minimum temperature $\left({ }^{\circ} \mathrm{C}\right)$ & SMW 4-12 & -0.72 \\
\hline 2 & Morning relative humidity (\%) & SMW 3-8 & -0.65 \\
\hline 3 & Morning relative humidity (\%) & SMW 11-12 & -0.57 \\
\hline 4 & Rainfall(mm) & SMW 52-3 & 0.53 \\
\hline 5 & Rainfall(mm) & SMW 6-12 & -0.56 \\
\hline 6 & Sunshine hours (hrs day-1) & SMW $49-51$ & 0.66 \\
\hline
\end{tabular}

Table 3: Verification of agrometeorological models developed for prediction of wheat productivity in central Punjab

\begin{tabular}{lccc}
\hline Year & Actual yield $\left(\mathrm{kg} \mathrm{ha}^{-1}\right)$ & Predicted yield $\left(\mathrm{kg} \mathrm{ha}^{-1}\right)$ & Departure $(\%)$ \\
\hline $2012-13$ & 4853 & 4670 & -3.7 \\
$2013-14$ & 5226 & 4800 & -8.2 \\
$2014-15$ & 4470 & 4110 & -8.1 \\
\hline
\end{tabular}

\section{Sensitivity of wheat growth stages to weather variations}

The correlation coefficients were worked out between weather parameters during different weeks/periods and wheat yield using data period from 2000-2001 to 2011-12 and three years (2012-13, 2013-14 and 2014-15) were used to validate the model. The maximum temperature during standard meteorological week (SMW) 46 - 47, minimum temperature during SMW 47-48, morning relative humidity during SMW 50 - 51, rain amount during SMW 52-53, sunshine hours during SMW 45-46, $49-52,4-6$ and number of rainy days during SMW 49, 1 - 2 were positively correlated with grain yield of wheat. However, the maximum temperature during SMW 3-4, 8-9, minimum temperature during SMW $50-52,4-12$, morning relative humidity during SMW 4-8, $11-12$, evening relative humidity during SMW 4-7, rain amount during SMW 6-12 and number of rainy days during SMW 5-12 were negatively correlated with the grain yield of wheat (Table 2).
The multiple regression equation was developed using mean minimum temperature (SMW 4-12) $\left(\mathrm{X}_{1}\right)$; mean rainfall amount (SMW 52-3) $\left(\mathrm{X}_{2}\right)$, mean rainfall amount (SMW 6 - 12) $\left(\mathrm{X}_{3}\right)$, mean sunshine hours (SMW 49-51) $\left(\mathrm{X}_{4}\right)$, mean morning RH (SMW 3-8 $\left(\mathrm{X}_{5}\right)$ and SMW $11-12$ $\left(\mathrm{X}_{6}\right)$ ).

$\mathrm{Y}=3069.2-102.52 \mathrm{X}_{1}+35.73 \mathrm{X}_{2}-6.52 \mathrm{X}_{3}+210.33 \mathrm{X}_{4}-$ $9.84 \mathrm{X}_{5}+24.79 \mathrm{X}_{6}$

$\left(\mathrm{R}^{2}=0.81\right)$

This equation could explain $81 \%$ variation in wheat grain yield. This model was validated with independent data of three years (2012-13 to 2014-15). The result showed that the model predicted wheat grain yield between 4110 to 4800 $\mathrm{kg} \mathrm{ha}^{-1}$ against the reported yield of 4470 to $5226 \mathrm{~kg} \mathrm{ha}^{-1}$, thus giving deviation of less than $8.2 \%$ in all the years (Table 3 ). The satisfactory performance of the model suggests that it can be used successfully for pre-harvest prediction of grain yield of wheat crop based on weather parameters in central plain region of Punjab. 


\section{CONCLUSIONS}

An overview of the study indicates that there is not any single weather parameter responsible for variations in crop productivity, but it is the combined effect of different meteorological variables specially minimum temperature, morning relative humidity, rainfall and number of rainy days during reproductive growth period of the crop. The model developed can be used for pre-harvest yield prediction of wheat at Ludhiana.

\section{REFERENCES}

Annonymous, (2015). Statistics of Punjab Agriculture. Punjab Agricultural University, Ludhiana.

Hundal, S. S. and Kaur, P. (2007). Climatic variability and its impact on cereal productivity in Indian Punjab. Current Science 92 (4): 506 - 512.

Rao, B. B., Chowdary, P. S., Sandeep, V. M., Pramod, V. P. and Rao, V. U. M. (2015). Spatial analysis of the sensitivity of wheat yields to temperature in India. Agric. For. Meteorol. 200: 192 - 202.

Received : September 2015 ; Accepted : April 2016 